\title{
nombalina
}

(i)

\section{Life Design and Career Construction in Children}
Autor(es):
Nota, Laura; Ginevra, Maria Cristina; Santilli, Sara; Maggio, Ilaria Di; Soresi, Salvatore

Publicado por: Imprensa da Universidade de Coimbra

URL persistente:

URI:http://hdl.handle.net/10316.2/43652

DOI:

DOI:https://doi.org/10.14195/978-989-26-1451-9_5

Accessed : $\quad$ 26-Apr-2023 15:55:05

A navegação consulta e descarregamento dos títulos inseridos nas Bibliotecas Digitais UC Digitalis, UC Pombalina e UC Impactum, pressupõem a aceitação plena e sem reservas dos Termos e Condições de Uso destas Bibliotecas Digitais, disponíveis em https://digitalis.uc.pt/pt-pt/termos.

Conforme exposto nos referidos Termos e Condições de Uso, o descarregamento de títulos de acesso restrito requer uma licença válida de autorização devendo o utilizador aceder ao(s) documento(s) a partir de um endereço de IP da instituição detentora da supramencionada licença.

Ao utilizador é apenas permitido o descarregamento para uso pessoal, pelo que o emprego do(s) título(s) descarregado(s) para outro fim, designadamente comercial, carece de autorização do respetivo autor ou editor da obra.

Na medida em que todas as obras da UC Digitalis se encontram protegidas pelo Código do Direito de Autor e Direitos Conexos e demais legislação aplicável, toda a cópia, parcial ou total, deste documento, nos casos em que é legalmente admitida, deverá conter ou fazer-se acompanhar por este aviso.

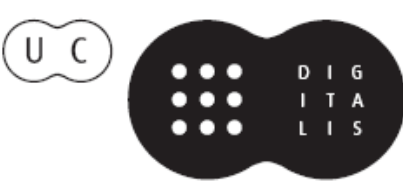


JOAQUIM ARMANDO FERREIRA MATTHIAS REITZLE

EDUARDO SANTOS (EDS.)

\section{CAREER \\ DEVELOPMENT \\ IN CONTEXT}

FESTSCHRIFT FOR

FRED VONDRACEK 


\title{
$\mathbf{V}$ \\ LI FE D E S I GNAND CAREER \\ CONSTRUCTION INCHILDREN
}

\author{
Laura Nota ${ }^{1}$; laura.nota@unipd.it \\ Maria Cristina Ginevra ${ }^{1}$; mariacristina.ginevra@unipd.it \\ Sara Santilli ${ }^{1}$; sara.santilli@unipd.it \\ Ilaria Di Maggio ${ }^{1}$; ilaria.dimaggio@phd.unipd.it \\ Salvatore Soresi ${ }^{1}$; salvatore.soresi@unipd.it \\ https://doi.org/10.14195/978-989-26-1451-9_5
}

\begin{abstract}
Fred Vondracek was one of the first scholars to highlight since at the beginning of 21 st century that vocational psychology should consider social and work context changes to help people to cope with the future times (Vondracek, Ferreira, \& dos Santos, 2010). In relation to this, and taking into account the rapid changes in the currently labor market, Fred Vondracek highlights the important roles of some positive resources, such as career adaptability, positive career orientation, proactive career behaviors (Hirschi, Lee, Porfeli, \& Vondracek, 2013).
\end{abstract}

\footnotetext{
${ }^{1}$ Larios Laboratory and University Center for Disability, Rehabilitation and Inclusion, University of Padova, Italy
} 
In this chapter, celebrating Fred Vondracek as a scholar who has greatly contributed to the development of our discipline and on the base of his reflections, theoretical assumptions of Life Design, and Psychology Youth Development approach, we consider some relevant resources to cope with difficult times that we are going through, such as hope, optimism, future orientation, resilience, occupational knowledge, and career adaptability. For each of those constructs research studies underscoring their role in personal and professional development in childhood, preadolescence, and adolescence, are presented. Then, as Fred Vondracek claimed, we highlighted the importance of involving people in vocational guidance projects, as soon as possible in order to prepare adults to cope with the today complex reality. The chapter also reports some important assessment tools useful to analyze strengths and improve training activity to promote positive resources such as hope, optimism, future orientation, resilience, occupational knowledge, and career adaptability.

Keywords: hope, optimism, future orientation, resilience, occupational knowledge, career adaptability.

\section{Introduction}

This chapter is part of a volume that honors Fred Vondracek's work and achievements. The aim of this contribution is to highlight the affinities and similarities that we have shared and still share with him. The strong beliefs connecting us with Fred Vondracek regard the attention paid to current socio-economic 
changes, the context, developmental age, and the processes that support an adaptive career development.

As is well known, we are experiencing a time of such great and rapid changes that it is difficult to have full awareness of them and adapt the pace of our own existence accordingly. To deal with the personal and social 'transitions' associated with them, people need to use sophisticated coping strategies to safeguard their work and future prospective, as well as their wellbeing and quality of life (Nota, Soresi, Ferrari, \& Ginevra, 2014). Fred Vondracek was one of the first scholars to highlight, at the beginning of 21st century, that vocational psychology should consider social and work context changes. In 2000, Vondracek and Hartung organized a symposium at the American Psychological Association Convention in Washington, D.C., emphasizing the need for new models, research paradigms, research methods, and methods of intervention, to help people to cope with the future times (Vondracek, Ferreira, \& Santos, 2010; Vondracek \& Hartung, 2002).

As regards the context, vocational psychology has always paid attention to the individual and the need for individuals to consider their life environments. Over time, an evolution of thinking has resulted in greater attention being paid to the fact that the context characterizes professional development and, consequently, that it must be seen not only as a "ground of exploration", but as a set of conditions that can characterize the career construction of individuals. We strongly believe that it is unavoidable to envisage the involvement of so many allies that can allow the creation of wide and fruitful collaborations and help career counselors to support hope, optimism, solidarity, and to favor changes and improvements useful to innovation and to make the most of the collective 
intelligence of mankind, thus encouraging its development (Nota et al., 2014; Savickas et al., 2009). Since 1986, Fred Vondracek, in the developmental-contextual theory, emphasized the role of context, defined as family, culture, and socioeconomic system (Vondracek, Lerner, \& Schulenberg, 1986), assuming the existence of bi-directional influences between the child, growing up within the proximal context of the family, and the child's extra-familial network, including school, peers, and part-time work experiences. More recently, he highlighted that the dynamic person-context interactions shape human development and stated that the contexts can modify the circumstances surrounding the developing person (Vondracek et al., 2010; Vondracek \& Porfeli, 2002, 2008).

Lastly, as concerns the third point of affinity, we are well aware that in our field research has very often focused on the transition from adolescence to adulthood, while developmental age and preadolescence have received much less attention. However, we can no longer think that this can still be done today. The children of the 21 st century live in a society characterized by rapid economic and technological changes, the so-called 'knowledge society', or 'information society' because of the substantial production and distribution of information (Masten \& Obradović, 2006). Thanks to technology, people can access and consult unlimited information and creatively produce innovative products (Thomas \& Sheth, 2011). It seems clear that in the actual social context competencies that differ considerably from the skills and knowledge demanded in the previous century are needed and should be developed as soon as possible (Savickas et al., 2009). All of that has already been highlighted as relevant by Fred Vondracek via his view that career development must be part of an effort to foster optimal human functioning. According to him, the 
goal of our field should be to enhance the strengths in any given individual with the resources for positive development present in the individual's contexts (Vondracek et al., 2010). In relation to this, and taking into account the changes in the labor market, Fred Vondracek highlights some positive resources, such as career adaptability, positive career orientation, proactive career behaviors (Hirschi, Lee, Porfeli, \& Vondracek, 2013; Hirschi \& Vondracek, 2009; Skorikov \& Vondracek, 2007), and claims that these skills and attitudes should be developed as soon as possible, from childhood, which is a crucial period for career development, in order to prepare adults to cope with a complex reality (Hartung, Porfeli, \& Vondracek, 2008). Based on that, we think that we and Fred Vondracek speak with a single voice on the issues mentioned above. And this can only echo the deeply shared underlying belief that, given such premises, career counseling must be at the service of the less privileged individuals of a population (Nota et al., 2014; Vondracek et al., 2010). With this chapter, we not only wish to celebrate Fred Vondracek as a scholar who has greatly contributed to the development of our discipline and to whom we owe so much, but, based on what we mentioned above, we would also like to address some issues dear to our hearts and propose some examples of actions that can be implemented in line with the principles and theoretical beliefs just described.

What drives us, and we know that Fred Vondracek will agree with us given that his work has always been open to different voices, is the wish to continue to foster the wave of modernization sweeping our field in order to give impulse to new forces and new energies and to facilitate a social transformation that profits from the changes underway to improve social and human conditions. 


\section{Resources for Life Design and career construction}

Current actual conditions may stimulate a negative vision about the future that is related to uneasiness, discomfort and confusion, and to a reduced propensity to think about multiple options, progress, and improvements in living conditions. Therefore, in 2006, at the beginning of the economic crisis that now is enveloping the Western world, an international group of scholars started to develop what is now known as the Life Design approach, aimed at providing answers to the crisis. After three years of work, they published the shared 'Manifesto' of the Life Design approach (Savickas et al., 2009). The Life Design approach states that career problems are only "a slice of the pie" of individual life, and that people need to understand how to handle postmodern life. It should specify skills and knowledge for the analysis of non-linear causalities, ecological settings, multiple subjective contexts, and complex dynamics. Moreover, it emphasizes the need to support people to become experts in co-construction and life design processes, to anticipate and deal with career transitions, and to consider hope for a foreseeable future, useful to individuals' future planning and behavior, and career adaptability, that is a modern world workers' essential resource to manage frequent career and life transitions (Nota et al., 2014; Savickas et al., 2009).

To create a sound foundation for all of this, it is necessary to involve children, as soon as possible, to promote their development of positive life trajectories. Moreover, this is in line with developments in the last decade to shift attention from a focus on deficits and problems during childhood and adolescence to increased valuing of positive aspects in the course of development. In fact, the new emphasis is on 'positive youth development' (PYD) (Lerner, von Eye, Lerner, \& Lewin-Bizan, 
2009). This is an approach that aims to overcome the negative view associated with the transition from childhood to adolescence, with the latter often conceptualized as absence or decrease of difficulties (Bowers, Li, Kiely, Brittian, Lerner, \& Lerner, 2010). Also Hartung, Porfeli, and Vondracek (2005) claimed that promoting positive development could increase the probability of reducing "the likelihood of delinquent and deviant behaviors, including alcohol and drug abuse" (p. 411). We like Vondracek et al. (2010)'s reference to systems theory proposed by Overton (2010), that state that the greater the integration between the individual's strengths and the resources of the context, the greater the positive development observed, the setting of goals, the optimal use of resources and strategies to achieve them, and the changes made to actions already started to pursue them if barriers are encountered or if strategies turn out to be inefficacious.

In line with that, over the last few years we have paid attention to some aspects that can be advantageous for the construction of positive pathways, such as hope, optimism, future orientation, resilience, occupational knowledge and career adaptability ${ }^{2}$.

\section{Positive development: The role of hope and optimism.}

Hope and optimism emerge in childhood and persist into the adult years (Masten \& Tellegen, 2012), and may be considered

\footnotetext{
${ }^{2}$ We are happy and proud to be able to say that we have collaborated with Fred Vondracek on the issue of adaptability within the Career Adaptability International Collaborative. The Collaborative was established in 2008 and involved scholars from about twenty different nations with the aim of studying this dimension.
} 
as antecedents of career and self-construction and prerequisites of career adaptability.

Hope is a motivational process based on three components: goals, pathways, and agency goal-directed thinking (Snyder, 2002). Research highlighted that hope is related to health and career outcomes in the course of development. Specifically, in childhood, preadolescence, and adolescence it is related to higher levels of life satisfaction, personal adaptation, adaptive achievement and less behavior problems and depressive symptoms (Kenny, Walsh-Blair, Blustein, Bempechat, \& Seltzer, 2010; Schmid, Phelps, Kiely, Napolitano, Boyd, \& Lerner, 2011). Regarding social development, hope is related to higher relational goals and more positive feelings about one's friendships, facilitating their stability over time (Stephanou, 2011). Lastly, during adolescence hope is related to school achievement and school life adaptation, higher levels of academic self-efficacy, mastery goal orientation, vocational identity, and satisfaction for educational plans (Diemer \& Blustein, 2007; Kenny et al., 2010).

Optimism represents a stable predisposition to "believe that good rather than bad things will happen" (Scheier \& Carver, 1985, p. 219). During the course of development, it is negatively associated with depression, anxiety, non-adaptive behaviors, risk of suicide, and positively correlated with physical health and life satisfaction (Malinauskas \& Vaicekauskas, 2013; Reivich, Gillham, Chaplin, \& Seligman, 2013). Similar to hope, optimism plays a relevant role in the quality of interpersonal relationships: it is associated with more positive relationships, higher social acceptance, and lower levels of loneliness and isolation (Oberle, Schonert-Reichl, \& Thomson, 2010). Lastly, regarding career development, Patton, Bartrum, and Creed (2004) showed that, in a group of high school students, optimism predicted career goals, career planning and career exploration. 
As regards our studies involving 3404 th- and $5^{\text {th }}$-grade students, we used two instruments that we developed to assess children's optimism and hope: What Will Happen to Me? and My Hope. Using these instruments, Ginevra, Carraro, and Zicari (2014) found that hope and optimism predicted social skills, life satisfaction and a positive self-perception. Moreover, they observed that hope and optimism correlated with resilience. In preadolescence, involving 692 middle school students, Santilli, Ginevra, Sgaramella, Nota, Ferrari and Soresi (2015) showed that hope and optimism correlated with life satisfaction, resilience, future orientation, and career adaptability. Lastly, involving adolescents, Wilkins, Santilli, Ferrari, Nota, Tracey, \& Soresi (2014) found that hope and optimism predicted indirectly, through four career adaptability resources, distinct satisfaction domains (school experiences, autonomous decision-making, classmate relations, family relations, praise received, help availability, and current life conditions).

Considering hope and optimism toward the future (see the questionnaire Visions About Future; Ginevra, Sgaramella, Ferrari, Nota, Santilli, \& Soresi, 2014), and based on Bryant and Cvengros' study (2004), which considered hope and optimism as dual indicators of a single global dimension reflecting future orientation in preadolescents and adolescents, Ginevra et al. (2014) found, through second-order confirmatory analyses, that orientation toward hope, optimism and pessimism are related but distinct constructs and can be considered as indicators of a single global dimension reflecting a positive orientation toward the future ${ }^{3}$. Santilli, Marcionetti, Rochat, Rossier, and Nota (2017), considering this global dimension as mediator, showed that

\footnotetext{
3 Orientation toward pessimism negatively saturated with the secondorder factor.
} 
positive orientation toward the future in Italian preadolescents partially mediated and in Swiss preadolescents fully mediated the relationship between career adaptability and life satisfaction.

\section{Positive development: The role of resilience and future orientation.}

Resilience and future orientation are two additional positive psychology constructs that play a crucial role in promoting more adaptive career development in current times (Masten, \& Tellegen, 2012).

Resilience concerns the ability of individuals to resist or quickly recover strengths and energy and to set themselves in motion while challenges are threatening stability, vitality and development (Masten \& Obradović, 2006). It is a protective factor to cope with risks, also related to future uncertainty and challenges of the 'risk society' in which we live. From childhood to adolescence, resilience is related to positive developmental outcomes and avoidance of maladaptive outcomes, and life satisfaction (Masten \& Tellegen, 2012). It is also related to coping and problem-solving skills, ability of asking for support, and better social relationships (Donald \& Clacherty, 2005). During preadolescence and adolescence, it correlates with higher school achievement, vocational identity, and career commitment (Diemer \& Blustein, 2007). Santilli et al. (2015), studying Italian preadolescents, showed that resilience positively correlated with future orientation, life satisfaction and career adaptability.

Future orientation refers to thoughts, ideas and feelings individuals have about their future (Stoddard, Zimmerman, \& Bauermeister, 2011). Future orientation skills develop throughout adolescence, starting from 11 -12 years old, even 
if Grisso et al. (2003) found that younger adolescents (11- to 13-year-olds) were significantly less likely to recognize the long-term consequences of various decisions than 16 years old and older adolescents and tended to accept more frequently an immediate rather than a delayed but more valuable reward. During preadolescence and adolescence, future orientation is a protective factor against impulsive and unhealthy behaviors, because it increases the ability to foresee negative consequences of certain actions and behaviors (Luyckx, Lens, Smits, \& Goossens, 2010). As regards educational and work outcomes, future-oriented adolescents, both in academic achievements and in their careers, tend to be more successful than present-oriented individuals (Simons, Vansteenkiste, Lens, \& Lacante, 2004). Moreover, propensity to look to the future is positively correlated with career maturity, operationalized in terms of career planning and exploration (Janeiro \& Marques, 2010). In the Italian context, Ferrari, Nota, and Soresi (2010), involving middle school students, highlighted that preadolescents with higher levels of future orientation were more greatly involved in the decisional process and more committed in school.

\section{Positive development: The role of occupational knowledge.}

Besides emphasizing the variables described above, Hartung et al. (2005) underline the importance of promoting in childhood occupational knowledge, which is associated with greater personal identity, career adaptability, and connectedness to the social and interpersonal world. Occupational knowledge regards the amount of knowledge that individuals think they have about a list of jobs (perception of occupational knowledge) and the amount of knowledge that they really have 
about jobs (actual occupational knowledge; Ferrari, Ginevra, Santilli, Nota, Sgaramella, \& Soresi, 2015; Rohlfing, Nota, Ferrari, Soresi, \& Tracey, 2012).

Although research studies on occupational knowledge in the course of development are not extensive (Rohlfing et al., 2012; Schmitt-Wilson \& Welsh, 2012) and conducted in a fragmented way (Schultheiss, 2005), the few studies conducted on this topic highlighted that knowledge about occupations and about self-in-occupations develops by age 10 or 11 and tends to improve with age (Hartung et al., 2005). It must be said, however, that the literature provides conflicting data on development trends: on one hand, Watson and McMahon (2005) found an age improvement in knowledge related to work aspects and job characteristics, while on the other hand, Schmitt-Wilson and Welsh (2012) did not find grade differences in occupational knowledge in children from 4th to 7 th grade. Also, Rolfing et al. (2012) found that elementary and middle school students' perception of knowledge of occupations did not differ across third through sixth grades.

Other studies highlighted that occupational knowledge is influenced by experience and that children tend to be more accurate in describing and assessing jobs they have already experienced (Howard \& Walsh, 2010). Furthermore, occupational knowledge is related to occupational preferences and stereotyped jobs; specifically, boys have more knowledge about realistic and investigative jobs and girls have more knowledge about social jobs (Miller \& Hayward, 2006). In an Italian study of elementary and middle school students, Ferrari et al. (2015) confirmed the role of experience on both perception of occupational knowledge and actual occupational knowledge on Holland's categories. Specifically, higher levels of actual occupational knowledge and perception of occupational knowledge 
were observed for social category (e.g., nurse and teacher), probably related to a higher exposure to these occupations, but also with comments shared at school, for instance on what teachers' work consists of, on reasons underlying his/her actions. Lower levels of actual occupational knowledge and perception of occupational knowledge were instead observed for conventional category (e.g., accountant and secretary), about which children have very limited experience. Moreover, the authors did not observe an increase in actual occupational knowledge with increasing age, suggesting that probably the progression of occupational knowledge is very slow. Conversely, with increasing age girls show higher scores in their perception of occupational knowledge for artistic categories, including an increase in the attention for the world of show biz and fashion in which girls invest more as they get older. Lastly, the authors found also a relationship between occupational knowledge and career exploration. The latter, defined as an action implemented for gathering appropriate knowledge both about self (e.g. interests and values) and about the world of education and work (e.g. education, training courses and occupations), predicted actual occupational knowledge rather than perception of occupational knowledge. Specifically, the more students were involved in exploration activities, the more their actual knowledge tended to improve.

\section{Positive development: The role of career adaptability.}

As suggested by Hirschi and Vondracek (2009), career adaptability plays a crucial role in favoring recursive and dynamic professional self-construction which takes into account the characteristics of today's labor market. 
Career adaptability is the readiness to cope with the predictable tasks of preparing for and participating in the work role and with the unpredictable adjustments prompted by the changes in work and work conditions (Savickas, 2013). Hartung (2015) and Hartung et al. (2008) stated that antecedents of career adaptability begin during childhood (e.g., autonomy, self-esteem, and future time orientation) and develop during preadolescence and adolescence, contributing to creating a more meaningful professional construction across the lifespan (Nota et al., 2014; Savickas, 2013). Studying preadolescents, Hirschi (2009) found that career adaptability predicted sense of growth power and life satisfaction, and in another study he showed that career adaptability was the best predictor of realism and stability of the aspirations (Hirschi, 2010).

Regarding studies of career adaptability in adolescence, Porfeli and Savickas (2012), involving a group of 460 10th and 11th grade U.S. students, observed that career adaptability was strongly correlated with vocational identity and, specifically, with in-depth career exploration and identification with career commitments. In turn, Pouyaud, Vignoli, Dosnon, and Lallemand (2012) found, in French adolescents, that career adaptability, and in particular concern, correlated significantly with motivation in educational environments; it also negatively correlated with general anxiety and the fear of failing in one's academic-professional path.

In the Italian context, Di Maggio, Ginevra, Nota, Ferrari, and Soresi (2015), besides confirming the factorial structure of the Career Adapt-Abilities Scale (Savickas \& Porfeli, 2012) in middle school students, showed that higher levels of career adaptability correlated with higher levels of hope, optimism, and life satisfaction, and lower levels of pessimism. Among highschool students, Soresi, Nota, and Ferrari (2012), observed that 
adolescents with higher levels of career adaptability showed lower perceived internal and external career barriers, a broader range of career interests, and higher quality of life than adolescents with lower levels of career adaptability. Moreover, we are interested in investigating, in a group of high school students, the relationship between career adaptability and vocational identity, operationalized in the VISA questionnaire developed by Porfeli, Lee, Vondracek, and Weigold (2011) as career exploration, commitment, and reconsideration dimensions.

It is exciting to be able to say that vocational psychology is currently focusing on positive aspects and resources that can be useful in promoting beneficial developmental pathways, starting with children. Fred Vondracek's appeals have been heeded and we can now witness greater enthusiasm in the realization of research studies, in setting up new tools, and in channeling attention also toward these aspects. We believe that it is now time to make further efforts, on the one hand on designing interventions and, on the other, on trying to include these different aspects into professional development models in a more complete and articulate way.

\section{Analyzing and enhancing strengths: suggestions for counselors' actions}

Considering the points examined, it seems clear that we need to give attention to positive aspects of growth and development and to implement interventions as early as possible (Hartung et al., 2005, 2008; Savickas et al, 2009). We think that children, preadolescents and adolescents should be involved in career interventions, cyclically and repetitively over time, aimed at stimulating an analysis of the strengths, above described, 
relevant for their career construction. These activities should include the assessment of these characteristics and stimulate specific reflections and changes.

\section{Assessment instruments to analyze strengths.}

To assess hope from childhood to adolescence, it is possible to use, for example, the Young Children's Hope Scale (YCHS) developed by McDermott, Hastings, Gariglietti, and Callahan (1997) for children aged 5 to 7 years, and the Children's Hope Scale developed by Snyder et al. (1997) for those aged 8 to 16 years. In the Italian context, to assess hope in 4th and 5th grade students, Ginevra, Carraro, et al. (2014) developed the self-report 'My Hope'. It consists of 6 items (e.g. "I think about how to get things that are important for me") on a 6-point scale ranging from 1 (never) to 6 (very often). The validity and reliability analyses showed good results, with a Cronbach's alpha of .77. For middle and high school students 'Visions about Future' was developed (Ginevra, Sgaramella, et al., 2014). The version for middle school students comprises 16 items on a 5-point Likert scale ( 1 = not strong; 5 = strongest), and assesses orientation toward hope ( 7 items, e.g. "In the future I will be involved in very important projects"), orientation toward optimism (4 items, e.g. "Even in the face of difficulties, I think I will remain an optimist"), and orientation toward pessimism (5 items, e.g. "It is useless to hope in the future: I will not be able to do what I have in mind"). The confirmative factor analysis carried out supported a second-order structure, regarding a general sense of positive orientation toward the future. Additionally, good levels of internal consistency were found (ranging from .76 to .91). The version for high school students consists of 22 items 
and has a similar structure to the version for middle school students, with equally good psychometric properties.

Just as for hope, there are several self-reports in the international literature to measure children's, preadolescents', and adolescents' optimism. We offer the following examples: the Optimism-Pessimism Test Instrument (Stipek, Lamb, \& Zigler, 1981) for children aged 6 to 12 years; the Youth Life Orientation Test (Ey et al., 2005) for children 7 to 16 years, and the Life Orientation Test (Scheier \& Carver, 1985) for children as young as 8-years-old. In the Italian context, Ginevra, Carraro, et al. (2014) developed the 6-item self-report scale What Will Happen to Me?, which measures on a 5 -point scale ( $1=$ I never think so $5=$ I always think so), the tendency to expect more positive than negative events. An example item is "I think more good things will happen to me than bad". The validity and reliability analyses conducted by the authors showed good results, with a Cronbach's alpha of .91 .

Several quantitative instruments may be used to assess resilience from childhood to adolescence, such as the Strengths and Difficulties Questionnaire (Goodman, 2001) for children aged 3 to 16 years old, the Child and Youth Resilience Measure-28 (Liebenberg, Ungar, \& Van de Vijver, 2012) for individuals ranging in age from 9 to 23 years. Regarding resilience about the future, Ginevra, Carraro, et al. (2014) developed the scale About Future, for 4 th and 5 th grade students. It consists of 7 items (e.g. "When something bad happens to me, I try to do something to solve the situation") with responses on a 5-point scale ranging from 1 (I never think so) to 5 (I always think so). The analyses carried out showed good psychometric requisites, with a Cronbach's alpha of .82 .

As regards self-report instruments to assess preadolescents' and adolescents' positive future orientation, we note the 
Adolescent Time Perspective Inventory developed by Mello and Worrell (2007). Focusing on future orientation and career resilience in the Italian context, Santilli et al. (2015) developed for middle and high school students the questionnaire Design My Future (see Table 1 for the version for middle school students). The version for middle school students consists of 21 items on a 5-point Likert scale ( $1=$ I never think so; $5=$ I always think so), and measures propensity to future orientation (13 items, e.g., "Looking ahead and thinking about what will happen in the future makes me feel full of energy") and propensity to resilience ( 8 items, e.g., "I think I'm able to challenge the difficult situations that may arise in the future for me"). The explorative and confirmative factor analyses carried out confirmed a two-factor correlated structure and good reliability (.88 for future orientation and .79 for resilience). The version for high school students, consisting of 25 items, has a similar structure to the version for middle school students, with equally good psychometric properties. 
Table 1. Design My Future - Version for middle school students

\section{DESIGN MY FUTURE}

- Version for middle school students

Santilli, S., Ginevra, M. C., Sgaramella, T. M., Nota, L., Ferrari, L., \& Soresi, S. (2015)

\section{Instructions}

Listed below is a set of statements which refer to things you could think or do. Please read them one at a time and while choosing an answer remember that:

1 stands for "it describes me very slightly"

2 stands for "it describes me slightly"

3 stands for "it describes me somewhat"

4 stands for "it describes me fairly well"

5 stands for "it describes me very well"

\begin{tabular}{|l|l|} 
& $\mathbf{2}$ \\
& 3
\end{tabular}


13. I think I'm a strong person.

14. I like to think about what I can do to have a good future.

15. I believe to achieve my goals.

16. I consider myself able to deal with anything that might happen.

17. I think I'm a person who does not get discouraged easily.

18. Imagining my future makes me feel optimistic.

19. When I think about my future I pay attention to the type of person I'd like to be.

20. I think I'm able to challenge the difficult situations that may arise in the future for me.

21 . I often think about how I wish things to be in the future.

Regarding occupational knowledge, several self-reports and structured interviews have been published to assess children's, preadolescents' or adolescents' perception of or actual knowledge of occupations and the world of work. Among these, we note the Revised Career Awareness Survey (McMahon \& Watson, 2001), and the Job Knowledge Survey (Loesch, Rucker, \& Shub, 1978). In the Italian context, Ferrari et al. (2015) developed the Occupational Knowledge Interview to assess children's perception of occupational knowledge and actual occupational knowledge. It consists of 12 cards, each depicting one occupation, 2 for every Holland's category: Realistic (airplane pilot, fireman), Investigative (pharmacist, veterinarian), Artistic (actor/actress, journalist), Social (nurse, school teacher), Enterprising (shop assistant, taxi driver) and Conventional (accountant, secretary). The interview consists of two sections: the first probes perception of knowledge in 12 occupations, using a 4-point Likert scale ( $1=I$ do not know; $4=I$ know very well); the second investigates actual 
occupational knowledge, asking participants to list any action, task or activity that is carried out by workers in the 12 occupations listed above. The percentage of agreement reached by two raters that codified the participants' answers for each occupation was $95 \%$.

Lastly, to assess preadolescents' and adolescents' career adaptability, the 24-items self-report Career Adapt-Abilities Scale (Savickas \& Porfeli, 2012) was developed by the research group Career Adaptability Research Team, coordinated by Mark Savickas. The instrument used in different countries with adolescents and adults has appropriate measurement equivalence, with six items for each subtest (concern, control, curiosity, and confidence), which in turn combine to become a global indicator of career adaptability (see the special issue by Leong \& Walsh, 2012). Recently, Di Maggio et al. (2015) validated the instrument in Italian preadolescents, and found good psychometric requisites, with good levels of internal consistency (ranging from .69 to .90). Moreover, the authors confirmed the hierarchical factor structure similarity to the CAAS-Italy Form for adolescents (Soresi et al., 2012) and to the CAAS-International form 2.0 (Savickas \& Porfeli, 2012).

\section{Working to support strengths.}

The analysis of strengths may allow one to elaborate, for each child, preadolescent or adolescent, a personalized report, which describes the variables considered and the scores obtained in these dimensions. The occasion when the report is given could be an opportunity to encourage children to reflect on the resources for their career construction and to identify their strengths. 
Small group sessions or individual educational activities can be designed, with ad-hoc materials such as online stories, videos, or illustrative examples, to present the resources considered and provide specific suggestions to promote them. In this respect, regarding hope and optimism, the laboratory "Nuggets of optimism and hope to school" (Ginevra, Carraro, et al., 2014), developed by the Larios laboratory and the international research group IHRT, could be implemented. The workshop lasts three hours and discusses the definition of optimism and the typical aspects of the optimistic person. By using specific examples from school and extra-school settings the children are trained to recognize optimistic thoughts and distinguish them from negative ones, thus highlighting the importance of some strategies and ways of thinking and doing which are optimistic for their growth and future. Then the workshop presents the children with the definition of hope and the characteristics of the hopeful person and with exercises to facilitate goal setting and the production of hopeful and optimistic ideas to pursue those goals. The workshop ends with the analysis of a peer's story to single out her optimistic thoughts and the strategies she used to achieve her goals. In order to verify the efficacy of this laboratory, 71 elementary and middle school students were involved. Each participant, at pre- and post-test, was asked to complete the following sentences: "The optimistic person is ...", and "The hopeful person is...". At the end of the laboratory, the participants expressed a clear understanding of the discussed topics and presented more precise characteristics of optimism and hope then pre-test.

As regards resilience and future orientation, it may be useful to stimulate preadolescents and adolescents to start writing the "Book of Their Life" (Niles \& Harris-Bowlsbey, 2005), beginning from significant past events. They could be supported to focus on 
the important consequences of those events in increasing their strengths, and in thinking back to their difficult past events, to identify the internal and external resources that allowed them to successfully deal with them. Moreover, they could be invited to 'project into the future' and write the chapter of the future, picturing themselves in five and ten years' time.

As regards knowledge of occupations and the world of work, we wish to mention a three-hour workshop "A leap into the world of work" (Ginevra, Carraro, et al., 2014), which encourages participants to consider the definition of work, its characteristics, and the rights and duties of workers. Participants are then stimulated to analyze occupations by describing actions, tools, places, people, knowledge, and skills required. In order to verify the efficacy of the laboratory, at pre- and post-test, participants were first asked the definition of work ("Work is ...”) at pre-test. At post-test, participants offered more complex, articulated definitions of work, and with more positive aspects (e.g., work allow to obtain economic benefits and to satisfy personal, psychological and social needs).

\section{Structured activities of involvement.}

In order to act even more incisively, and also to implement prevention activities and avoid the onset of vulnerability (Vondracek et al., 2010), several trainings could be implemented to promote hope, optimism, future orientation, resilience, occupational knowledge, and career adaptability.

Regarding hope and optimism, we want to note the preventive program developed by Firpo (2001), aimed at promoting elementary school students' optimistic attributional style, and the program proposed by McDermott and Hastings (2000), in 
which school children (grades 1-6) were read stories of highhope children, and classroom discussions addressed how these children might incorporate hope into their own lives. Moreover, we recognize the social-ecological program "Building Hope for the Future", developed by Marques, Lopez, and Pais-Ribeiro (2011), that includes hope-based sessions with high school students as well as direct work with their parents and teachers.

In the promotion of resilience and future orientation, the PATHS curriculum could be used (Greenberg, 2006) to reduce impulsive behaviors and to facilitate future time orientation and consequential thinking before taking action. Moreover, we want to recognize the intervention developed by Marko and Savickas (1998) to increase high school and college students' positive future orientation. Lastly, for the Italian context, Ferrari, Nota, and Soresi (2012) developed and verified effectiveness of a structured 10-unit didactic intervention to foster adolescents' future orientation and career decidedness. The program "Hopes and expectations for the future" aims to increase ability to project into the future and build one's own career project with greater competence and awareness.

To improve occupational knowledge, career interventions generally aim to promote career exploration. Among these interventions, we want to take note of the program proposed by Beale (2000) that, through movies, graphic activities, group readings and group discussions, promotes the exploration of specific working environments. Also the program by Fouad (2001), through guided tours, and discussions with workers, aims at enhancing occupational knowledge and career exploration. In the Italian context, Nota, Ginevra, and Santilli (2015) devised a ten-unit program for elementary and middle school students called "Journey into the world of professions and work". It encourages children to stimulate reflection on what work is 
and how professions can be explored in order to learn about them and to analyze their various aspects. Emphasis is placed on positive, open, and hopeful attitudes to work; concentration is focused on change, on the importance of innovation and creativity, and on the advantages of integration at the workplace. It was observed that at the end of this intervention, students of the experimental group showed higher levels of optimism and hope, future orientation, information, career exploration and curiosity, and more extensive occupational knowledge than a control group that did not participate in the training.

Concerning specific programs developed and validated to promote career adaptability, we want to recoignize Koen, Klehe, and Van Vianen's (2012) training, although its effectiveness has been verified only with college students, and Nota et al.'s (2015) training, made up of 7 didactic units (3 hours each) for high school students. This latter intervention aims at promoting a positive, optimistic and hopeful attitude about the future, mental open-mindedness, creativity, career exploration, ability to identify career goals and self-efficacy beliefs to pursue one's goals.

Lastly, as an example of an intervention that uses new technologies and provides career activities for large groups of students at low cost, we present an online career program, based on the Life Design approach (Nota, Santilli, \& Soresi, 2016). It is a six-hour online intervention, developed to support middle school students to reflect on some relevant resources of their professional planning. The program is carried out in three meetings (steps), and each step begins with a 15-minute video in which the first two authors propose specific reflections on variables that the students will later be asked to reflect on. Specifically, the first video (first step) focuses on the importance of looking toward the future, to take responsibility for their future; the second video (second step) highlights the 
importance of investing in education and training, considering that we live in what is called the 'knowledge society'; the third video (third step) focuses on the advantages associated with having multiple goals and also multiple ways to focus on personal goals. After the presentation of the video in the first and second meeting, the participants are administered online questionnaires that invite them to rate themselves on those same variables. Then, at the end of the second meeting, they receive a personalized report representing the strengths they recognize in themselves. In the third meeting, after the video, the students are encouraged to write down two goals in line with their strengths and their wishes, also in other areas of their life (love relationships, leisure activities, contribution to society) where they could make the most of their strengths. The analyses carried out by the authors to verify the effectiveness of the program showed that, at post-test, middle school students that participated in this online-program had higher levels of career adaptability and life satisfaction than control group. Moreover, regarding their wishes about the future, they endorsed more key aspects of the Life Design approach, such as self-determination and attention to choice processes, description of work activities rather than a specific job, indication of dreams/expectations/goals about their future, strengths, life satisfaction, relationships and training investment.

\section{Conclusions}

Starting from Fred Vondracek's reflections, and based on theoretical assumptions of the Life Design and PYD approaches, in this chapter we have considered some relevant resources to cope with difficult times that we are going through, such 
as hope, optimism, future orientation, resilience, occupational knowledge, and career adaptability. For each of those constructs we have presented research studies underscoring their role in personal and professional development in childhood, preadolescence, and adolescence. Then, as Fred Vondracek himself maintains, we have again stated the importance of involving children, adolescents, and preadolescents in early vocational guidance projects. We have also focused on some important assessment tools useful for analyzing strengths and on some interventions that may be implemented to promote the development of the positive resources described above.

Although we can certainly say that a great deal has been done in that regard, we would like to conclude this chapter by focusing attention again on another area closely connected with young people's professional life, where much remains to be done: parent involvement. If we care about positive pathways, we cannot ignore family members, as Fred Vondracek said as far back as the 1980s (Schulenberg et al., 1984). We believe this point to be crucial and we strongly wish to join Fred Vondracek in stating again the importance of the family setting in young people's professional development and of involving parents in vocational guidance projects. We think that the present and the future of individuals affect not only them deeply, but they also deeply influence their contexts and their relationships, the most important of which are located in their families. We like to think with Vondreacek et al. (2010) that the issue of planning the future of children, of adolescents, and of young people is never exclusively individual and private, but relational and public. Therefore, we think that when vocational guidance services arrange for initiatives to support career choice and professional planning, they should also arrange for workshops and projects specifically for 'parents and family members' to 
help them make available to their children's future the resources and strengths that they certainly have or that should in any case be boosted and activated by such initiatives.

We believe that research in our field should insist on that and work in order to set up and validate projects that will allow parents to experience a fruitful and articulate involvement in constructing multiple positive occupational pathways for their children, while at the same time getting satisfaction and improved quality of life. In concluding this work we would like to recall this sentence by Fred Vondracek, who already anticipated: "a focus on family processes related to parental employment, parent-child relationships, socialization practices, and perhaps to family interaction patterns is a fruitful domain within which to explain vocational outcomes and to identify processes" (Schulenberg et al., 1984, p. 139).

\section{References}

Beale, A. V. (2000). Elementary school career awareness: A visit to a hospital. Journal of Career Development, 27(1), 65-72.

Bowers, E. P., Li, Y., Kiely, M. K., Brittian, A., Lerner, J. V., \& Lerner, R. M. (2010). The five Cs model of positive youth development: A longitudinal analysis of confirmatory factor structure and measurement invariance. Journal of Youth and Adolescence, 39 (7), 720-735.

Bryant, F., \& Cvengros, J. (2004). Distinguishing hope and optimism: Two sides of a coin, or two separate coins? Journal of Social and Clinical Psychology, 23, 273-302.

Di Maggio, I., Ginevra, M. C., Nota, L., Ferrari, L., \& Soresi, S. (2015). Career Adapt-Abilities Scale-Italian Form: psychometric properties with Italian preadolescents. Journal of Vocational Behavior, 91, 46-53.

Diemer, M. A., \& Blustein, D. L. (2007). Vocational hope and vocational identity: Urban adolescents' career development. Journal of Career Assessment, 15(1), 98-118.

Donald, D., \& Clacherty, G. (2005). Developmental vulnerabilities and strengths of children living in child-headed households: A comparison with children in adult-headed households in equivalent impoverished communities. African Journal of AIDS Research, 4(1), 21-28. 
Ey, S., Hadley, W., Allen, D. N., Palmer, S., Klosky, J., Deptula, D., \& Cohen, R. (2005). A new measure of children's optimism and pessimism: The youth life orientation test. Journal of Child Psychology and Psychiatry, 46(5), 548-558.

Ferrari, L., Ginevra, M. C., Santilli, S., Nota, L., Sgaramella, T. M., \& Soresi, S. (2015). Career Exploration and Occupational Knowledge in Italian Children. International Journal for Educational and Vocational Guidance, 15 (2), 113-130. Doi: 10.1007/s10775-015-9299-1.

Ferrari, L., Nota, L., \& Soresi, S. (2010). Time perspective and indecision in young and older adolescents. British Journal of Guidance \& Counselling, 38(1), 61-82.

Ferrari, L., Nota, L., \& Soresi, S. (2012). Evaluation of an intervention to foster time perspective and career decidedness in a group of Italian adolescents. The Career Development Quarterly, 60(1), 82-96.

Firpo, H. (2001). A Prevention program based on positive psychology for elementary school-aged children (Unpublished doctoral dissertation). Carlos Albizu University, Puerto Rico.

Fouad, N. A. (2001). Career linking: an intervention to promote math and science career awareness. Journal of Counseling and Development, 73, 527- 534.

Ginevra, M. C., Carraro, F., \& Zicari, S. (2014). Psicologia positiva e i bambini dei nostri tempi [Positive psychology and the children of our times]. In L. Nota \& S. Soresi (Eds.), La psicologia positiva a scuola e nei contesti formativi (pp. 7-21). Firenze: Hogrefe.

Ginevra, M. C., Sgaramella, T. M. Ferrari, L., Nota, L., Santilli, S., \& Soresi S. (2016). Visions About Future: A new scale assessing optimism, pessimism and hope in adolescents. International Journal for Educational and Vocational Guidance, 17(2), 187-210.

Goodman, R. (2001). Psychometric properties of the strengths and difficulties questionnaire. Journal of the American Academy of Child \& Adolescent Psychiatry, 4O(11), 1337-1345.

Greenberg, M. T. (2006). Promoting resilience in children and youth. Annals of the New York Academy of Sciences, 1094(1), 139-150.

Grisso, T., Steinberg, L., Woolard, J., Cauffman, E., Scott, E., Graham, S., \& Schwartz, R. (2003). Juveniles' competence to stand trial: A comparison of adolescents' and adults' capacities as trial defendants. Law and Human Behavior, 27(4), 333.

Hartung P. J. (2015). Life Design in Childhood: Antecedents and advancement. In L. Nota \& J. Rossier (Eds.), Life Design Handbook (pp. 89-101). Göttingen: Hogrefe.

Hartung, P. J., Porfeli, E. J., \& Vondracek, F. W. (2005). Child vocational development: A review and reconsideration. Journal of Vocational Behavior, 66(3), 385-419.

Hartung, P. J., Porfeli, E. J. \& Vondracek, F. W. (2008). Career adaptability in childhood. The Career Development Quarterly, 57, 63-74.

Hirschi, A. (2009). Career adaptability development in adolescence: Multiple predictors and effect on sense of power and life satisfaction. Journal of Vocational Behavior, 74(2), 145-155. 
Hirschi, A. (2010). The role of chance events in the school-to-work transition: The influence of demographic, personality and career development variables. Journal of Vocational Behavior, 77(1), 39-49.

Hirschi, A., Lee, B., Porfeli, E. J., \& Vondracek, F. W. (2013). Proactive motivation and engagement in career behaviors: Investigating direct, mediated, and moderated effects. Journal of Vocational Behavior, 83(1), 31-40.

Hirschi, A., \& Vondracek, F. W. (2009). Adaptation of career goals to self and opportunities in early adolescence. Journal of Vocational Behavior, 75(2), 120-128.

Howard, K. A., \& Walsh, M. E. (2010). Conceptions of career choice and attainment: Developmental levels in how children think about careers. Journal of Vocational Behavior, 76(2), 143-152.

Janeiro, I. N., \& Marques, J. F. (2010). Career coping styles: Differences in career attitudes among secondary school students. International Journal for Educational and Vocational Guidance, 10(1), 35-48.

Kenny, M. E., Walsh-Blair, L. Y., Blustein, D. L., Bempechat, J., \& Seltzer, J. (2010). Achievement motivation among urban adolescents: Work hope, autonomy support, and achievement-related beliefs. Journal of Vocational Behavior, 77(2), 205-212.

Koen, J., Klehe, U. C., \& Van Vianen, A. E. (2012). Training career adaptability to facilitate a successful school-to-work transition. Journal of Vocational Behavior, 81(3), 395-408.

Leong, F. T., \& Walsh, W. B. (2012). Guest editors' introduction to the special issue. Journal of Vocational Behavior, 80(3), 659-660.

Lerner, R. M., von Eye, A., Lerner, J. V., \& Lewin-Bizan, S. (2009). Exploring the foundations and functions of adolescent thriving within the 4- $\mathrm{H}$ study of positive youth development: A view of the issues. Journal of Applied Developmental Psychology, 30 (5), 567-570.

Liebenberg, L., Ungar, M., \& Van de Vijver, F. (2012). Validation of the child and youth resilience measure-28 (CYRM-28) among Canadian youth. Research on Social Work Practice, 22(2), 219-226.

Loesch, L. C., Rucker, B. B, \& Shub, P. A. (1978). A field test of an instrument for assessing job knowledge. Measurement and Evaluation in Guidance, 11(1), 26-32.

Luyckx, K., Lens, W., Smits, I., \& Goossens, L. (2010). Time perspective and identity formation: Short-term longitudinal dynamics in college students. International Journal of Behavioral Development, 34(3), 238-247.

Malinauskas, R., \& Vaicekauskas, A. (2013). Well-being, activity, mood and optimistic way of thinking of adolescent athletes. Health Sciences, 23 (2 (87)), 25-27.

Marko, K. W., \& Savickas, M. L. (1998). Effectiveness of a career time perspective intervention. Journal of Vocational Behavior, 52(1), 106-119.

Marques, S. C., Lopez, S. J., \& Pais-Ribeiro, J. L. (2011). "Building hope for the future": A program to foster strengths in middle-school students. Journal of Happiness Studies, 12(1), 139-152.

Masten, A. S., \& Obradović, J. (2006). Competence and resilience in development. Annals of the New York Academy of Sciences, 1094(1), 13-27. 
Masten, A. S., \& Tellegen, A. (2012). Resilience in developmental psychopathology: Contributions of the project competence longitudinal study. Development and Psychopathology, 24(02), 345-361.

McDermott, D., \& Hastings, S. (2000). Children: Raising future hopes. In C. R. Snyder (Ed.), Handbook of hope: Theory, measures, and applications (pp. 185-199). San Diego, CA: Academic Press.

McDermott, D., Hastings, S. L., Gariglietti, K. P., \& Callahan, B. (1997). The development of the young children's hope scale. Unpublished manuscript.

McMahon, M., \& Watson, M. B. (2001). Revised Career Awareness Survey. Unpublished manuscript.

Mello, Z. R., \& Worrell, F. C. (2007). The adolescent time inventory-English (Unpublished scale). University of California, Berkeley.

Miller, L., \& Hayward, R. (2006). New jobs, old occupational stereotypes: Gender and jobs in the new economy. Journal of Education and Work, 19(1), 67-93.

Niles, S. G., \& Harris-Bowlsbey, J. (2005). Career development interventions in the 21st century. New Jersey, NJ: Pearson/Merrill Prentice Hall.

Nota, L., Ginevra, M. C., \& Santilli, S. (2015). Life Design and prevention. In L. Nota \& J. Rossier (Eds.), Life Design handbook (pp. 183-199). Göttingen: Hogrefe.

Nota, L., Santilli, S., \& Soresi, S. (2016). A Life-Design-Based Online Career Intervention for Early Adolescents: Description and Initial Analysis. The Career Development Quarterly, 64 (1), 4-19. doi:10.1002/cdq.12037.

Nota, L., Soresi, S., Ferrari, L., \& Ginevra, M. C. (2014). Vocational designing and career counseling in Europe: Challenges and new horizons. European Psychologist, 19(4), 248.

Oberle, E., Schonert-Reichl, K. A., \& Thomson, K. C. (2010). Understanding the link between social and emotional well-being and peer relations in early adolescence: Gender-specific predictors of peer-acceptance. Journal of Youth and Adolescence, 39, 1330-1342.

Overton, W. F. (2010). Life-span development: Concepts and issues. Handbook of life-span development, 1, 1-29.

Patton, W., Bartrum, D. A., \& Creed, P. A. (2004). Gender differences for optimism, self-esteem, expectations and goals in predicting career planning and exploration in adolescents. International Journal for Educational and Vocational Guidance, 4(2-3), 193-209.

Porfeli, E. J., Lee, B., Vondracek, F. W., \& Weigold, I W. (2011). A multidimensional measure of vocational identity status, Journal of Adolescence, 34(5), 853-871.

Porfeli, E. J., \& Savickas, M. L. (2012). Career Adapt-Abilities Scale-USA Form: Psychometric properties and relation to vocational identity. Journal of Vocational Behavior, 80(3), 748-753.

Pouyaud, J., Vignoli, E., Dosnon, O., \& Lallemand, N. (2012). Career AdaptAbilities Scale-France Form: Psychometric properties and relationships to anxiety and motivation. Journal of Vocational Behavior, 80(3), 692-697. 
Reivich, K., Gillham, J. E., Chaplin, T. M., \& Seligman, M. E. P. (2013). From helplessness to optimism: The role of resilience in treating and preventing depression in youth. In. S. Goldstein \& R. B. Brooks (Eds.), Handbook of resilience in children (pp. 201-214). New York, NY: Springer US.

Rohlfing, J. E., Nota, L., Ferrari, L., Soresi, S., \& Tracey, T. J. (2012). Relation of occupational knowledge to career interests and competence perceptions in Italian children. Journal of Vocational Behavior, 81(3), 330-337.

Santilli, S., Ginevra, M. C., Sgaramella, T. M., Nota, L., Ferrari, L., \& Soresi, S. (2015). Design My Future: An instrument to assess future orientation and resilience. Journal of Career Assessment. Advance online publication.

Santilli, S., Marcionetti, J., Rochat, S., Rossier, J., Nota, L. (2017). Career adaptability, hope, optimism and life satisfaction in Italian and Swiss adolescents. The Journal of Career Development, 44(1), 62-76.

Savickas, M. L. (2013). Career construction theory and practice. In S. D. Brown \& R. W. Lent (Eds.), Career development and counseling. Putting theory and research to work (2nd ed.) (pp. 144-180). Hoboken, NJ: John Wiley.

Savickas, M. L., Nota, L., Rossier, J., Dauwalder, J. P., Duarte, M. E., Guichard, J., ... \& Van Vianen, A. E. M. (2009). Life designing: A paradigm for career construction in the 21st century. Journal of Vocational Behavior, 75(3), 239-250.

Savickas, M. L., \& Porfeli, E. J. (2012). Career Adapt-Abilities Scale: Construction, reliability, and measurement equivalence across 13 countries. Journal of Vocational Behavior, 80(3), 661-673.

Scheier, M. F., \& Carver, C. S. (1985). Optimism, coping, and health: Assessment and implications of generalized outcome expectancies. Health Psychology, 4, 219-247.

Schmid, K. L., Phelps, E., Kiely, M. K., Napolitano, C. M., Boyd, M. J., \& Lerner, R. M. (2011). The role of adolescents' hopeful futures in predicting positive and negative developmental trajectories: Findings from the 4-H Study of Positive Youth Development. The Journal of Positive Psychology, 6 (1), 45-56.

Schmitt-Wilson, S., \& Welsh, M. C. (2012). Vocational knowledge in rural children: A study of individual differences and predictors of occupational aspirations and expectations. Learning and Individual Differences, 22(6), 862-867.

Schulenberg, V., \& Vondracek, F. W., \& Crouter, A. C. (1984). The influence of the family on vocational development. Journal of Marriage and the Family, 46, 129-149.

Schultheiss, D. E. P. (2005). Elementary career intervention programs: Social action initiatives. Journal of Career Development, 31(3), 185-194.

Simons, J., Vansteenkiste, M., Lens, W., \& Lacante, M. (2004). Placing motivation and future time perspective theory in a temporal perspective. Educational Psychology Review, 16(2), 121-139.

Skorikov, V., \& Vondracek, F. W. (2007). Positive career orientation as an inhibitor of adolescent problem behaviour. Journal of Adolescence, 30(1), 131-146. 
Snyder, C. R. (2002). Hope theory: Rainbows in the mind. Psychological Inquiry, 13(4), 249-275.

Snyder, C. R., Hoza, B., Pelham, W. E., Rapoff, M., Ware, L., Danovsky, M., ... \& Stahl, K. J. (1997). The development and validation of the Children's Hope Scale. Journal of Pediatric Psychology, 22(3), 399-421.

Soresi, S., Nota, L., \& Ferrari, L. (2012). Career Adapt-Abilities Scale-Italian Form: Psychometric properties and relationships to breadth of interests, quality of life, and perceived barriers. Journal of Vocational Behavior, $80(3), 705-711$.

Stephanou, G. (2011). Children's friendship: The role of hope in attributions, emotions and expectations. Psychology, 2 (8), 875-888.

Stipek, D. J., Lamb, M. E., \& Zigler, E. F. (1981). OPTI: A measure of children's optimism. Educational and Psychological Measurement, 41(1), 131-143.

Stoddard, S. A., Zimmerman, M. A., \& Bauermeister, J. A. (2011). Thinking about the future as a way to succeed in the present: A longitudinal study of future orientation and violent behaviors among African American youth. American Journal of Community Psychology, 48(3-4), 238-246.

Thomas, C., \& Sheth, A. (2011). Web wisdom: An essay on how web 2.0 and semantic web can foster a global knowledge society. Computers in Human Behavior, 27 (4), 1285-1293.

Vondracek, F. W., Ferreira, J. A. G., \& Santos, E. J. R. (2010). Vocational behavior and development in times of social change: new perspectives for theory and practice. International Journal for Educational and Vocational Guidance, 10(2), 125-138.

Vondracek, F. W., Ford, D. H., \& Porfeli, E. J. (2014). A Living systems theory of vocational behavior and development. Rotterdam: Sense Publishers.

Vondracek, F. W., \& Hartung, P. J. (2002). Introduction: Innovating career development using advances in life course and life-span theory. Journal of Vocational Behavior, 61(3), 375-380.

Vondracek, F. W., Lerner, R. M., \& Schulenberg, J. E. (1986). Career development: A life-span developmental approach. Hillsdale, NJ: Erlbaum.

Vondracek, F. W., \& Porfeli, E. (2002). Integrating person-and function-centered approaches in career development theory and research. Journal of Vocational Behavior, 61(3), 386-397.

Vondracek, F. W., \& Porfeli, E. J. (2008). Social contexts for career guidance throughout the world. Developmental-contextual perspectives on career across the lifespan. In J. A. Athanasou \& R. Van Esbroeck (Eds.), International handbook of career guidance (pp. 209-225). Springer Netherlands.

Watson, M., \& McMahon, M. (2005). Children's career development: A research review from a learning perspective. Journal of Vocational Behavior, 67(2), 119-132.

Wilkins, K. G., Santilli, S., Ferrari, L., Nota, L., Tracey, T. J., \& Soresi, S. (2014). The relationship among positive emotional dispositions, career adaptability, and satisfaction in Italian high school students. Journal of Vocational Behavior, 85(3), 329-338. 